\title{
世帯間関係の組み合わせパタンと住宅敷地所有・利用関係の分析
}

ーインド洋津波後のスリランカにおける住宅移転をともなう再定住に関する研究その 2 -

\section{ANALYSIS ON COMBINATION PATTERN OF HOUSEHOLD-RELATIONSHIP AND OWNER/USER-RELATIONSHIP OF HOUSING SITE}

- A study on resettlement with housing relocation in Sri Lanka after the Indian Ocean Tsunami in 2004 Part 2-

前田昌弘*, 高田光 雄**, 神吉 紀世子***

\section{Masahiro MAEDA, Mitsuo TAKADA and Kiyoko KANKI}

\begin{abstract}
In this paper, we clarified how relationships in local community are reorganized by focusing on economic relationship in housing relocation in Sri Lanka after the Indian Ocean Tsunami in 2004. We selected the resettlement site G which has high stable settlement ratio (nearly 90\%) in Welligama, Southern Province. We selected 86 households living at "site G" as of January in 2009 and analyzed reorganization process and combination pattern of their neighborhood relationship, blood relationship, Micro Credit's relationship and owner/user-relationship of housing site. As a result, relationships in existing local communities have been maintained at previous settlement or succeed at "site G" and Micro Credit's relationship is probably essential for residents' economic. We also verified that Micro Credit's relationship is probably maintained or succeeds without neighborhood nor blood relationship and therefore it has feature of selective relationship which is important for residents' initiative.
\end{abstract}

\section{Keywords : Housing Relocation, Resettlement, Local Community, Neighborhood, Micro Credit} 住宅移転，再定住，地域コミュニティ，地縁，マイクロクレジット

\section{1. 序論}

\section{1. 研究の背景と目的}

近年、自然災害からの復興過程において、被災地外への住宅移転 が不可避的に発生し被災者の生活再建が困難化する問題が顕在化し ている。本研究はこのような問題に着目し、被災者が住宅移転自体 によって生活再建を妨げられることなく再定住地へと移住すること ができる再定住地計画のあり方を探ることを目標としている注1)。

筆者らはこれまで、インド洋津波（2004 年 12 月）後の住宅復興に おいて大量の住宅移転と再定住地建設が発生したスリランカを対象 として津波被災者の再定住地一の移住に関する調查を行ってきた主2)。 前稿 ${ }^{3)}$ では、上記の調查を踏まえ、再定住地一と移住する被災者 の生活再建をサポートする関係（地縁関係、血縁関係、経済的な関 係など）と住宅敷地所有・利用関係の再編に着目して、被災者の再 定住を体系的に分析する枠組みを構築した。そして、住宅移転の影 響が特に大きいと予想されるスリランカ南部・ウェリガマ郡の津波 被災集落の分析を通じて分析枠組みの有効性を検証した。その上で 「従前居住地完結型」、「再定住地完結型」、「従前居住地－再定住地補 完型」という 3 つの再定住パタンを抽出した。

本稿で再定住地への移住の事例を分析するにあたり、2008 年 12 月 にウェリガマ郡の再定住地・全 14 ケ所の実態を調査した。すると、 入居後 $1 \sim 2$ 年が経過して定住率が著しく低下している事例が多く みられた注3)。そんな中、再定住地 $\mathrm{G}$ は入居後 2 年が経過した 2008
年 12 月時点においても約 $90 \%$ という高い定住率を保っており、被災 者の生活再建が比較的良好に進んでいると推測される事例である。

前稿 ${ }^{3)}$ で検討したように、再定住地への移住において従前コミュ ニティにおける居住者間の関係を全て再定住地へと継承する「再定

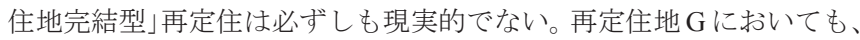
居住者間の関係を部分的であれ維持・継承する「従前居住地一再定 住地補完型」に近い再定住が行われていると推測される。

さらに、被災者の生活再建において特に経済の回復が重要である と考えられることから、本稿では経済的関係であるマイクロクレジ ット注4)（Micro Credit;MC）の関係に着目し、その維持・継承の機構 を探る。後述するように、 MC の関係の維持・継承を理解する上で、 $\mathrm{MC}$ がどのような居住者に必要とされているか、MC の関係と他の関 係にどのような関連性があるかなど、MCの関係の地域性を把握す る必要がある。そこで本稿では、居住者の経済状況を把握した上で、 経済活動の単位である「世帯」を分析単位として、MCの関係、地縁 関係、血縁関係の再編実態の把握と組み合わせパタンの分析を行う。

以上の背景を踏まえ本稿では、津波被災者の再定住地 $\mathrm{G}$ への移住 の事例において、従前の地域コミュニティにおける居住者間の関係 がどのように再編されているかを、マイクロクレジット（MC）の関 係の維持・継承に着目して明らかにすることを目的とする。

\section{2. 既往研究と本研究の位置づけ}

本研究は、自然災害後の住宅復興における既存の地域コミュニテ

\footnotetext{
* 京都大学大学院工学研究科 博士後期課程 $\cdot$ 修士 $($ 工学 $)$

** 京都大学大学院工学研究科 教授. 博士 (工学)

*** 京都大学大学院工学研究科 准教授. 博士 (工学) 
イの維持・継承のあり方に関する研究に位置づけられる。

わが国では、阪神・淡路大震災（1995 年）からの復興過程において、 地域コミュニティの基盤である人間関係や居住空間の特徵への配慮 を欠いた住宅復興の問題が指摘された。例えば、復興公営住宅供給 が本来多様である被災者の住宅再建過程を単線化したこと主5)、災害 復興公営住宅への入居が地域コミュニティの「崩壊」や高齢者の孤 独死の発生を招いたこと注 6) などの問題が指摘された。

新潟県中越地震（2004 年）では、阪神・淡路大震災の教訓や中山 間地域の社会背景を考慮して、住宅復興において既存の集落コミュ ニティを維持・継承する枠組みが採用されたと言われている主7。多 くの応急仮設住宅において集落単位での入居が行われ、従前集落の 住宅の位置関係で部屋割が決められた事例も報告されている注8)。

このように、わが国では近年における災害復興の経験を通じて、 既存の地域コミュニティを維持・継承する住宅復興の重要性が認識 されつつある。しかし、例えば上記した新潟県中越地震の仮設住宅 地などは、地縁関係の維持という、やや一面的な地域コミュニティ 像にもとづいた計画であり、地域コミュニティ内の多様で複雑な関 係が必ずしも十分には考慮されていなかったと考えられる主9)。

本稿は、住宅復興において居住者の生活再建を年ポートする関係 として、地縁関係、血縁関係、MCの関係という性質の異なる関係に 着目し、その再編過程の分析を通じて住宅復興における地域コミュ ニティの維持・継承のあり方を探ることをめざした研究である。

\section{3. 研究の方法}

本稿は 4 章で構成される。第 1 章は序論である。本稿の目的を達 成するために、研究対象地域における「世帯」および「世帯間関係」

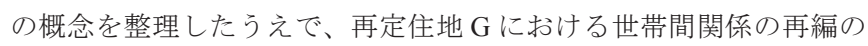
実態を把握する。その上で世帯間関係（地縁関係、血縁関係、MC の 関係）の組み合わせパタンと住宅敷地所有・利用関係の分析を行い、 $\mathrm{MC}$ の関係の維持・継承と他の世帯間関係の関連性を検証する。

第 2 章ではまず、スリランカのシンハラ人社会における「世帯」 および「世帯間関係」の概念を、文化人類学分野の既往研究を参照 しながら整理する。つぎに、調查対象である再定住地 $\mathrm{G}$ の概要と従 前居住地のペラナ村およびミリッサ村の特徵を述べ、2008 年 11 月か ら 2009 年 1 月にかけて実施した実地調查の内容と分析方法を述べる。

第 3 章ではまず、調査結果をもとに再定住地 $\mathrm{G}$ における世帯間関 係と住宅敷地所有・利用関係の再編の全体像を記述する。つぎに、 $\mathrm{MC}$ の関係と血縁関係に着目して世帯間関係の組み合わせを 4 パタン に分類する。そして、「住宅移転前の従前居住地」、「住宅移転後の従 前居住地」、「再定住地」という住宅移転の各段階における組み合わ せパタンと住宅敷地所有・利用関係の分析を行い、MCの関係の維持・ 継承と地縁関係、血縁関係、住宅敷地所有・利用関係の関連性を検 討する。なお、上記の分析は、従前居住地がペラナ村かミリッサ村 によって居住者の経済的安定性が異なることを踏まえて行う。

第 4 章では、本稿で得られた知見をまとめ、住宅復興における地 域コミュニティの維持・継承のあり方について考察し、結論とする。

\section{2. 研究対象地域の概要と調査内容について}

\section{1. シンハラ人社会の家族構造}

社会人類学者の中根千枝は、本研究が対象とするシンハラ人社会 を「両親とその未婚の子供から成る小家族」の家族構造モデルに該
当する社会の典型例に位置づけている注 ${ }^{10)}$ 。

シン八ラ人社会では一般的に、結婚した子供はすべて親から独立 した住居を構え、生計の単位としても自立した世帯を形成すること が理想とされている注11)。現実には、結婚した子供が親と同居する場 合もあるが、その場合も子供世帯と親世帯は食事および生計の単位 を明確に区別し、それぞれが自立した世帯を形成している注 ${ }^{12)}$ 。

一方で、シン八ラ人社会では血縁・親族関係を通じて日常的に労 働の共有や金銭・贈物の交換が行われている。また、インド洋津波 後の非常時にも金銭や住居などの緊急支援が行われた注13)。さらに、 研究対象地域では MCや「シートゥワ」と呼ばれる頼母子講の活動 が盛んであり、各世帯を代表して主に女性が活動に参加している。

このように、シン八ラ人社会では、「世帯」が経済単位として自立 しつつも、世帯間にお互いの生活をサポートする関係が形成されて おり、本稿ではこういった居住者間の関係を「世帯間関係」と呼ぶ。

\section{2. 調査対象の概要とその選定理由}

\section{（1）スリランカ南部・ウェリガマ郡の津波被災集落と再定住地}

図 1 に本稿の研究対象地域であるスリランカ南部ウェリガマ郡に おける再定住地と従前村の分布を示した。同郡では、住宅復興にお いて被災前の住宅数の約 $12.3 \%$ にあたる 1147 戸が全 14 ケ所の再定 住地において供給された注 14)。地域コミュニティの単位である「ワッ

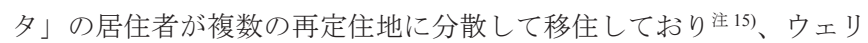
ガマ郡は住宅移転の影響が特に大きいと予想される地域である。

\section{（2）２つの津波被災集落ーペラナ村とミリッサ村}

図 1 に本稿の調查対象である再定住地 $\mathrm{G}$ およびその従前居住地で あるペラナ村、ミリッサ村の位置を示した。また、図 2 にペラナ村 およびミリッサ村から再定住地一の世帯移動を示した。各村の規模 は、ペラナ村が 511 世帯、ミリッサ村が 410 世帯であり、それぞれ「ワ ッタ」と呼ばれる集落で構成される注16)。図 3 にペラナ村・ワッタ $\mathrm{C}$ の住宅配置と世帯分布を示した。ワッタは通常、50〜 60 世帯前後で

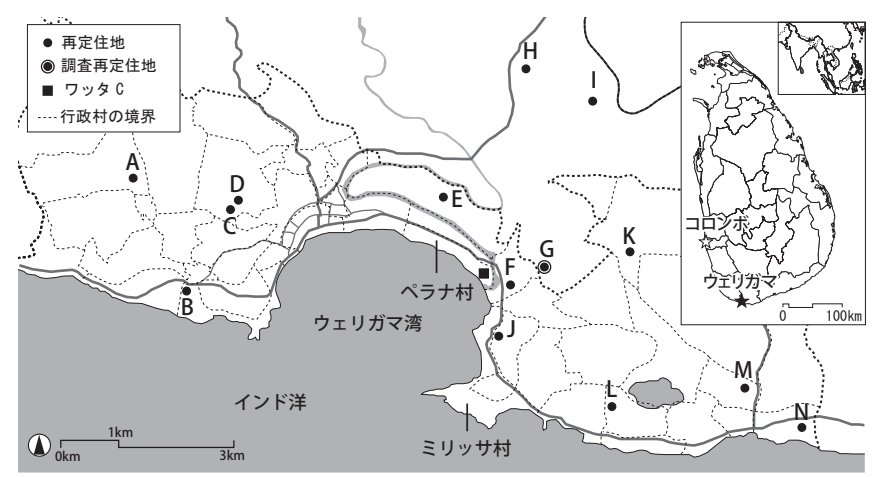

図 1 ウェリガマ郡における再定住地と従前村の分布（筆者作成）

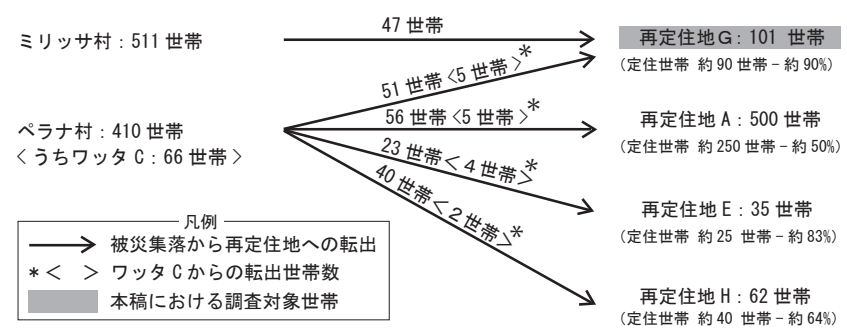

図 2 被災集落から再定住地一の世帯移動之調査対象世帯 (筆者による調査をもとに作成、2009 年 1 月現在) 
構成される地縁・血縁をべースとした小規模な集落である。

\section{（3）調査対象再定住地・事例 G}

図 4 に再定住地 $\mathrm{G}$ の住宅配置と世帯分布を示した。再定住地 $\mathrm{G}$ は ウェリガマ湾から約 $1 \mathrm{~km}$ 内陸の丘陵地帯に位置し、101 戸の戸建て 住宅から成る。再定住地 $\mathrm{G}$ に転入した 101 世帯の従前村の内訳は、 ペラナ村が 51 世帯、ミリッサ村が 47 世帯、その他の村が 3 世帯である。

表 1 に、2008 年 11 月時点で調査可能であった再定住地 $\mathrm{G}$ 居住者 83 世帯 (ペラナ村 47 世帯、ミリッサ村 33 世帯、その他の村 3 世帯) の特徵を従前村別に示した。ペラナ村とミリッサ村の居住者はとも に漁業を主な生業とするが、ペラナ村は昔ながらの漁業に従事する 者が多く、近代的な漁業に従事するミリッサ村に比べて経済的に不 安定である注 17)。再定住地 $\mathrm{G}$ 居住者も約 6 割が漁業に従事するが、ペ ラナ村からの世帯はミリッサ村からの世帯に比べて漁業収入が不安 定である。なお、住宅移転の影響で漁業を継続できなくなった居住 者はみられなかった。居住者の家族形態は、約 8 割が核家族形態で あり、住宅移転前に比べて核家族形態の割合が増加している。

再定住地 $\mathrm{G}$ を調査対象とした理由はまず、居住者の定住率が約 90\%とウェリガマ郡の他の再定住地と比べて高く、従前の居住者間 の関係が何らかの形で維持・継承されていると推測されるからであ る注 18)。また、居住者の経済的安定性に差異がみられ、居住者間の関 係の変化にある程度の多様性が観察されると推測されるからである。

\section{3. 調査内容と分析方法}

2008 年 11 月時点で再定住地 $\mathrm{G}$ に定住する 90 世帯のうち調査可能 な 86 世帯を対象として、世帯間関係 (地縁関係、血縁関係、MC の関係) と住宅敷地所有・利用関係を把握した。本稿において地縁関係は「同 じワッタおよび再定住地に居住する世帯のまとまり」、血縁関係は「2 親等以内の親族が構成員に含まれる世帯のまとまり」注 19$) 、 \mathrm{MC}$ の関 係は「同じ MC グループに所属する世帯のまとまり」とする注 20)。

前稿 3) でも検討したように、MC の関係は、居住者が参加するグル ープを自ら選択するという意味で選択的関係であり、地縁関係や血 縁関係といった非選択的関係とは異なる。また、MCの関係は、グル ープ運営を支援する外部者（NGO や行政の職員など）が介在する関 係であり、友人関係（親しい友人など）、生業上の関係（漁業組合な ど）、宗教上の関係（寺院組織など）といった、基本的に居住者のみ で形成される関係とは異なる。本稿では、居住者が自ら選択するこ とで生活再建に主体的に取り組み、かつ居住者だけでなく外部の者 との関係を活用できる関係として MC の関係に特に着目する。

ただし、MCのグループが地縁・血縁関係者で占められることも実 際にはあり、MCの関係には選択的関係であるとは言い切れない側面 もある。そこで本稿は世帯間関係の組み合わせパタンの分析を通じ て複数の関係の関連性を検討し、調查地域において MCの関係が地縁・ 血縁以外の者との間でも維持・形成される関係であるかを検証する。

なお、調査は再定住地 $\mathrm{G}$ で活動する地元 $\mathrm{NGO}$ 職員の協力を得て、 2008 年 5 月に予備調查を行い、2008 年 11 月から 2009 年 1 月にかけ て世帯間関係の聞き取りと住宅敷地所有・利用関係の聞き取りおよ び目視調查を行った。調査には英語とシンハラ語を併用した。

\section{3.世帯間関係の組み合わせパタンと住宅敷地所有・利用関係の分析 3. 1. 世帯間関係の再編過程の全体像}

図 5 は、調査結果をもとに、住宅移転前後における再定住地 $\mathrm{G}$ 居

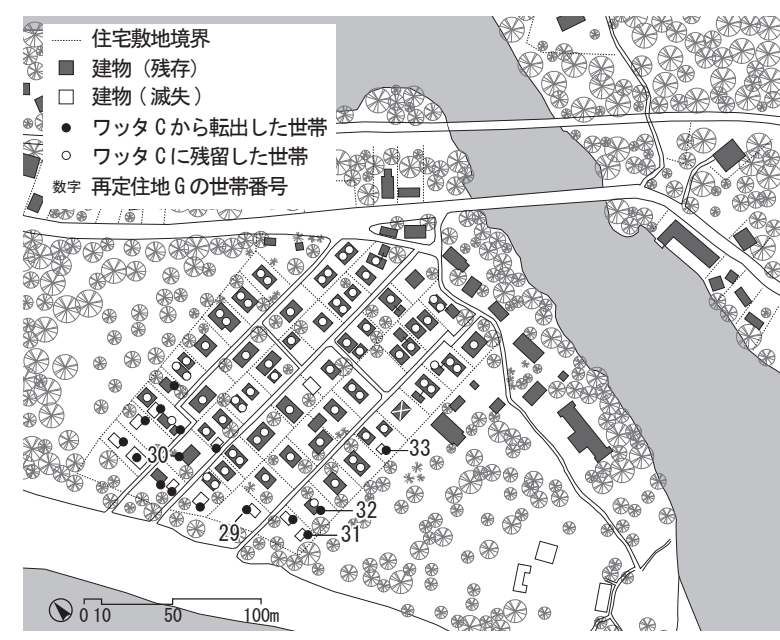

図 3 ワッタ C の住宅配置と世帯分布（筆者作成）

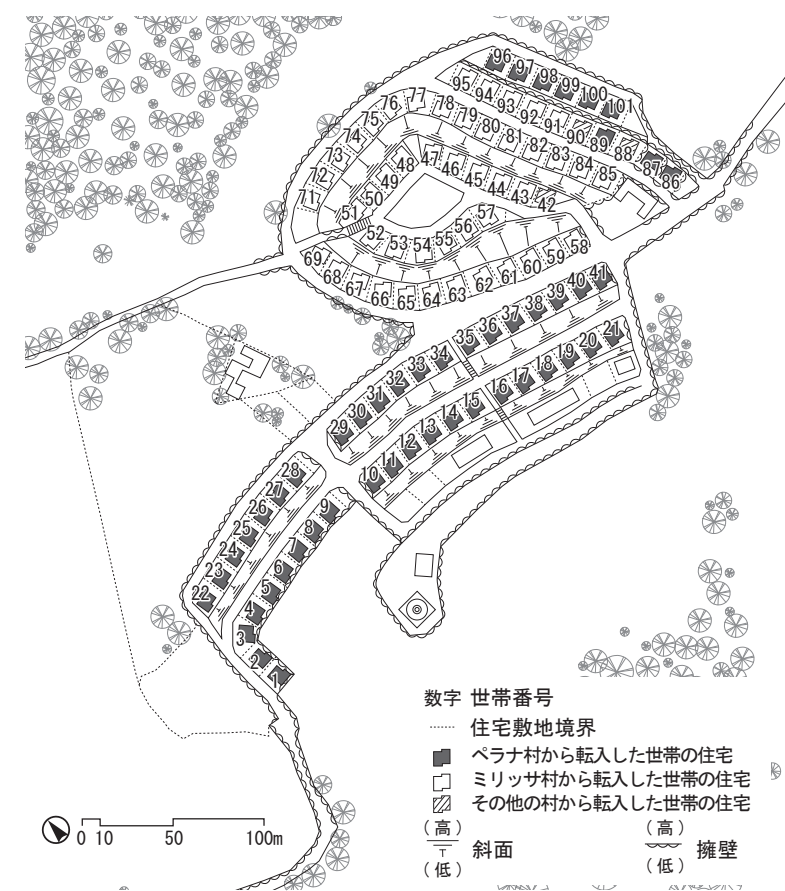

図 4 再定住地 $\mathrm{G}$ の住宅配置と世帯分布（筆者作成）

表 1 従前村別にみた再定住地 $\mathrm{G}$ 居住者の特徴（2009 年 1 月現在）

\begin{tabular}{|c|c|c|c|c|}
\hline & & & ペラナ村 & $\begin{array}{l}\text { ミリッサ村 } \\
\text { その他の村 }\end{array}$ \\
\hline \multicolumn{3}{|c|}{ 転入世帯数 } & 51 & 50 \\
\hline \multicolumn{3}{|c|}{ 定住世帯数 } & 49 & 41 \\
\hline \multicolumn{3}{|c|}{ 調査世帯数 } & 47 & 36 \\
\hline \multicolumn{3}{|c|}{ 人口（人） } & 211 & 164 \\
\hline \multirow{10}{*}{ 職業 } & \multirow{3}{*}{ 漁業 } & 動力無し漁船使用者 & 26 & 25 \\
\hline & & 動力付き漁船使用者 & 7 & 16 \\
\hline & & 流通·加工業従事者 & 8 & 4 \\
\hline & \multirow{4}{*}{ 漁業以外 } & 工場勤務者 & 6 & 7 \\
\hline & & 自営業・家内産業者 & 12 & 8 \\
\hline & & 日雇い労働者 & 3 & 0 \\
\hline & & その他の職業従事者 & 5 & 2 \\
\hline & \multirow{2}{*}{\multicolumn{2}{|c|}{$\begin{array}{c}\text { 計 (人) } \\
\text { 漁業徉事者率 }(\%)\end{array}$}} & 67 & 62 \\
\hline & \multirow{2}{*}{\multicolumn{2}{|c|}{$\begin{array}{l}\text { 漁業従事者率 (\%) } \\
\text { 漁業収入安定性 }\end{array}$}} & 61.7 & 72.6 \\
\hline & & & 不安定 & 比較的安定 \\
\hline \multirow{7}{*}{ 家族 } & \multirow{3}{*}{$\begin{array}{l}\text { 核家族 } \\
\text { 世帯数 }\end{array}$} & 夫婦と未婚子女 & 38 & 23 \\
\hline & & 夫婦のみ & 2 & 1 \\
\hline & & 母または父と未婚子女 & 2 & 3 \\
\hline & \multirow{2}{*}{$\begin{array}{c}\text { 拡大家族 } \\
\text { 世帯数 }\end{array}$} & 親と同居 & 4 & 7 \\
\hline & & 親および兄弟と同居 & 1 & 0 \\
\hline & \multicolumn{2}{|c|}{ その他の家族形態の世帯数 } & 0 & 2 \\
\hline & \multicolumn{2}{|c|}{ 計（世帯） } & 47 & 36 \\
\hline
\end{tabular}




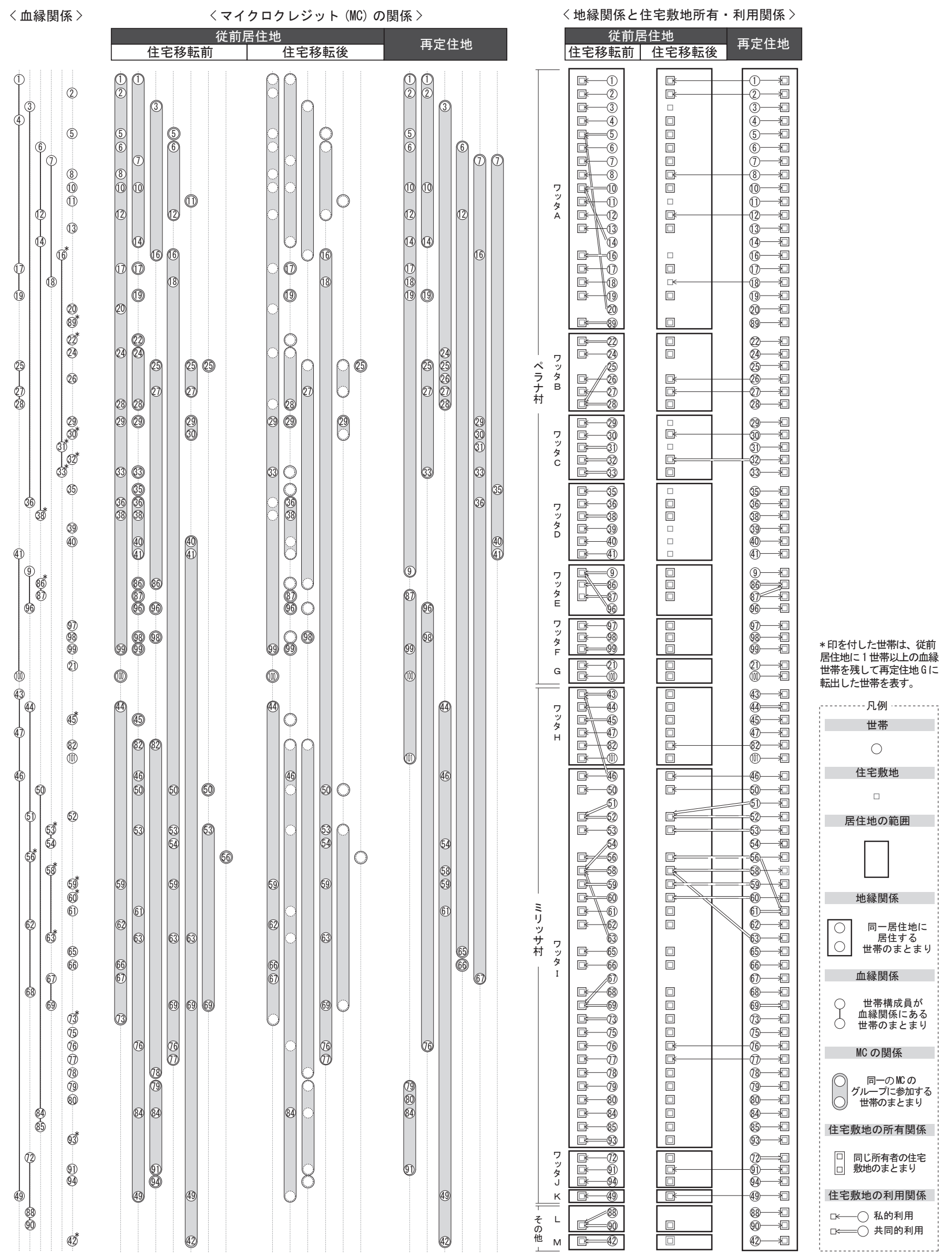

図 5 再定住地 $\mathrm{G}$ 居住者の世帯間関係と住宅敷地所有 - 利用関係の変化の全体像 
住者 86 世帯の世帯間関係と住宅敷地所有・利用関係の再編過程を、 前稿 ${ }^{3)}$ で構築した再定住の分析枠組みを用いて記述したものである。

図 5 から、再定住地 $\mathrm{G}$ 居住者の 59 世帯が住宅移転前に従前居住地 において MC の関係を有していたこと、30世帯が住宅移転後の従前 居住地において MC の関係を有すること、49世帯が再定住地におい て MC の関係を有することがわかる。また、56 世帯が住宅移転前に 従前居住地において血縁関係を有していたこと、19 世帯が住宅移転 後の従前居住地において血縁関係を有すること、45世帯が再定住地 において血縁関係を有することがわかる。また図 4 と図 5 から、居 住者の従前ワッタは計 13 ヶ所であり、従前ワッタの地縁関係が維持 されるように再定住地の住宅配置が決められていることがわかる。

このように、再定住地 $\mathrm{G}$ では従前居住地における $\mathrm{MC}$ の関係、血 縁関係、地縁関係が部分的ではあるが維持・継承されている。

なお、居住者が「 $\mathrm{MC}$ の関係を有する」とは、居住者が MCグルー プに参加することを意味する。例えば、「住宅移転後の従前居住地に おいて MC の関係を有する」とは、再定住地居住者が従前居住地に おいて活動する MCグループに参加することを意味する。

また、居住者が「血縁関係を有する」とは、血縁世帯が同じ居住 地に居住することを意味する。例えば、「住宅移転後の従前居住地に おいて血縁関係を有する」とは、再定住地居住者の血縁世帯が従前 居住地に居住することを意味する (図 5 で*を付した世帯)。

\section{2. 世帯間関係の組み合わせの分類}

世帯間関係の組み合わせパタン（以下、組み合わせパタン」）には、 「MC の関係と血縁関係ともに有する」(パタン I )、「MC の関係のみ 有する」(同 II )、「血縁関係のみ有する」(同 III )、「血縁関係と MC の関係ともになし」（同IV）の4 パタンがある。
表 2 は、「住宅移転前の従前居住地」「「住宅移転後の従前居住地」、 「再定住地」の各段階において、再定住地 $\mathrm{G}$ 居住者がどの組み合わせ パタンと住宅敷地所有・利用関係を有するかを示したものである。

再定住地 $\mathrm{G}$ 居住者 86 世帯が、「住宅移転前の従前居住地」におい て有した組み合わせパタンの内訳は、パタン I が 39 世帯、パタン II が 20 世帯、パタンIIIが 17 世帯、パタンIVが 10 世帯であった。

なお、地縁関係は組み合わせの要素から除外している。これは、 全ての居住者が「住宅移転前の従前居住地」の地縁関係を有してい たこと、「住宅移転後の従前居住地」の地縁関係を有さないこと、「再 定住地」の地縁関係を有寸ることが自明だからである。ただし、再 定住地における従前居住地の地縁関係（同じ村およびワッタから転 入した世帯のまとまり）については表 2 に示し 3.4 で別途検討する。

\section{3. 世帯間関係の組み合わせパタンの変化の分析}

表 3 は、再定住地 $\mathrm{G}$ 居住者が「住宅移転前の従前居住地」におい て有した組み合わせパタンが、「住宅移転後の従前居住地」において どのように変化したかを示したものである。表 4 は、再定住地 $\mathrm{G}$ 居 住者が「住宅移転前の従前居住地」において有した組み合わせパタ ンが、再定住地においてどのように変化したかを示したものである。

\section{（1）組み合わせパタン I （MC の関係と血縁関係ともに有する）}

「住宅移転前の従前居住地」において組み合わせパタンI を有して いた再定住地 $\mathrm{G}$ 居住者 39 世帯が、「住宅移転後の従前居住地」にお いて有するパタンの内訳は、パタン I が 6 世帯、パタン II が 18 世帯、 パタンIIIが 7 世帯、パタンIVが 8 世帯であった（表 3)。つまり、従 前居住地において約 $62 \%$ の世帯（パタン I ， II）が地縁によらずに $\mathrm{MC}$ の関係を維持しており、特に約 $46 \%$ の世帯（パタンII）は地縁・ 血縁によらずに MCの関係を維持している。

表 2 再定住地 $\mathrm{G}$ 居住者の世帯間関係の組み合わせパタンと住宅敷地所有・利用関係

\begin{tabular}{|c|c|c|c|c|}
\hline \multicolumn{2}{|c|}{ 組み合わせ } & \multicolumn{2}{|c|}{ 従前居住地 } & \multirow[b]{2}{*}{ 3）再定住地 } \\
\hline 番 & 血縁 $N$ & 1）住宅移転前の従前居住地 & 2) 住宅移転後の従前居住地 & \\
\hline \multirow{2}{*}{ I } & 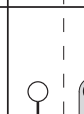 & 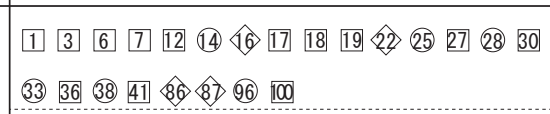 & (16) 38 & 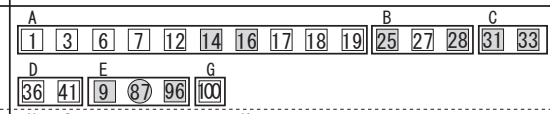 \\
\hline & $\begin{array}{r}1 \\
0 \\
1 \\
1 \\
1\end{array}$ & 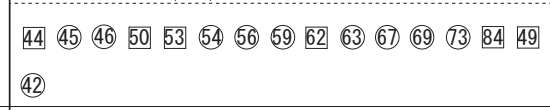 & 45 53 (59) 63) & 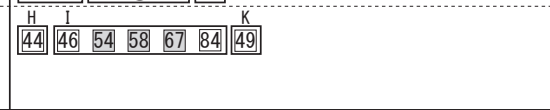 \\
\hline \multirow{2}{*}{ II } & $\begin{array}{l}1 \\
1 \\
1\end{array}$ & 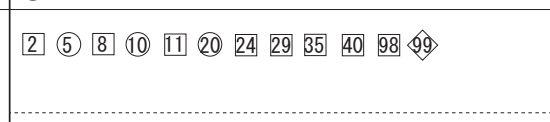 & $\begin{array}{lllllllllllll}17 & 19 & 25 & 27 & 28 & 29 & 36 & 87 & 96 & 98 & 99 & 100\end{array}$ & 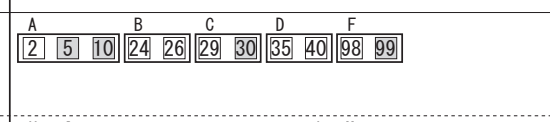 \\
\hline & & 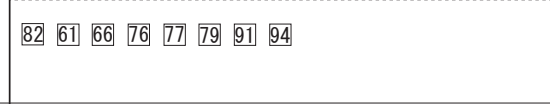 & $\begin{array}{lllllllllll}46 & 50 & 54 & 62 & 66 & 67 & 69 & 76 & 77 & 84\end{array}$ & 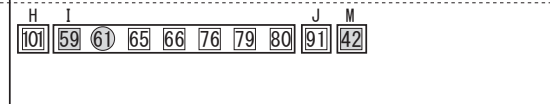 \\
\hline \multirow[b]{2}{*}{ III } & $\begin{aligned} 1 \\
1 \\
0\end{aligned}$ & 4 (9) 89 (31) (32) & 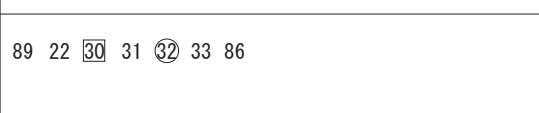 & \begin{tabular}{|l|l|l|}
$A$ & $D$ & $E$ \\
4 & 38 & 86 \\
\end{tabular} \\
\hline & $\begin{array}{r}1 \\
0 ! \\
1 \\
\end{array}$ & (43) 47 (51) (58) 60 $68 \quad 78 \quad 85 \quad 93 \quad 72 \quad(88)$ & (56) (58) (60 (13) $93 \quad 42$ & 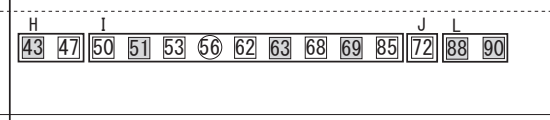 \\
\hline \multirow[b]{2}{*}{$\mathrm{IV}$} & $\begin{array}{l}1 \\
1 \\
1 \\
1\end{array}$ & 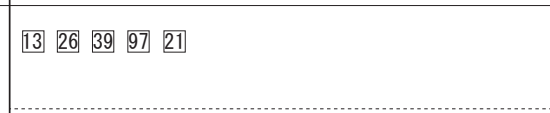 & \begin{tabular}{|c|cccccccccccccc}
1 & 2 & 3 & 4 & 5 & 6 & 7 & 8 & 10 & 11 & 12 & 13 & 14 & 20 & 24 \\
26 & 35 & 39 & 40 & 41 & 9 & 97 & 21 & &
\end{tabular} & 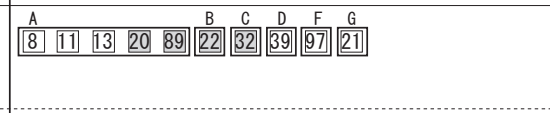 \\
\hline & i & 101 52) $65 \quad 75 \lcm{80}$ & 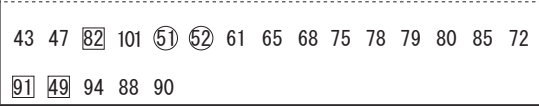 & 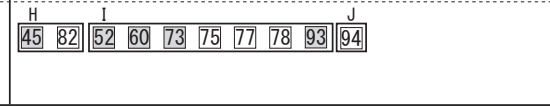 \\
\hline \multirow{2}{*}{\multicolumn{2}{|c|}{ ( 凡例 ) }} & 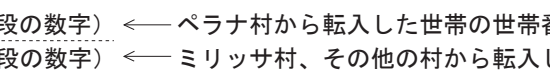 & $\begin{array}{ll}\text { 番号 (図 4, 図 } 5 \text { と対応) } & \text { 英字 } \\
\text { た世帯の世帯番号 (図 4, 図 } 5 \text { と対応) } & \text { 数字 }\end{array}$ & $\begin{array}{l}\text { ワッタ名 (図 } 5 \text { と対応) } \\
\text { 数字 } \longleftarrow \text { 同じワッタから転入した世帯のまとまり }\end{array}$ \\
\hline & & 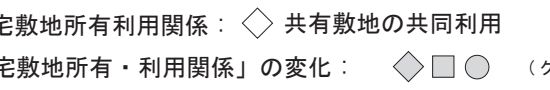 & $\begin{array}{l}\text { 私有敷地の共同利用 } \quad \square \text { 私有敷地の私 } \\
\text { (レー) } \\
\cdots\end{array}$ & $\begin{array}{lll}\text { し的利用 } & \text { なし } & \text { 利用なし } \\
\square \bigcirc & \text { (シロ } & \cdots \text { 変化がなかったもの }\end{array}$ \\
\hline
\end{tabular}


表 3 従前居住地における住宅移転前から住宅移転後への 組み合わせパタンの変化

\begin{tabular}{|c|c|c|c|c|c|}
\hline \multirow{2}{*}{\multicolumn{2}{|c|}{$\begin{array}{l}\text { 移転後の } \\
\text { 従前居住地 } \\
\text { (2) } \\
\text { (1) } \\
\text { 移転前の } \\
\text { 従前居住地 }\end{array}$}} & I & II & III & IV \\
\hline & & 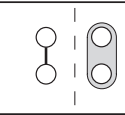 & $\begin{array}{l}1 \\
1 \\
1\end{array}$ & $\begin{array}{l:}0 \\
0 \\
0 \\
0\end{array}$ & $\begin{array}{l} \\
1 \\
1 \\
1\end{array}$ \\
\hline \multirow{2}{*}{ I } & 010 & 1638 & $\begin{array}{lllll}17 & 18 & 19 & 25 & 27 \\
28 & 36 & 87 & 96 & 100\end{array}$ & 22863033 & $\begin{array}{ccccc}1 & 3 & 6 & 7 & 12 \\
14 & 41 & & & \end{array}$ \\
\hline & $0: 0$ & 45535963 & $\begin{array}{l}44 \quad 46505462 \\
67 \quad 6984\end{array}$ & 567342 & 49 \\
\hline \multirow{2}{*}{ II } & $\begin{array}{ll}1 \\
10\end{array}$ & & 299899 & & $\begin{array}{ccccc}2 & 5 & 8 & 10 & 11 \\
20 & 24 & 35 & 40 & \end{array}$ \\
\hline & (1) & & 667677 & & 8261799194 \\
\hline \multirow{2}{*}{ III } & $\begin{array}{ll}1 \\
1 \\
0 & 1\end{array}$ & & & 893132 & 49 \\
\hline & $\begin{array}{r}0 \\
1 \\
1 \\
1 \\
1\end{array}$ & & & 586093 & $\begin{array}{l}4347516878 \\
85728890\end{array}$ \\
\hline \multirow{2}{*}{ IV } & $\begin{array}{l}1 \\
1 \\
1\end{array}$ & & & & 1326399721 \\
\hline & ! & & & & 10152657580 \\
\hline
\end{tabular}

また、パタン I を有していた 39 世帯が再定住地において有するパ タンの内訳は、パタン I が 25 世帯、パタン II が 3 世帯、パタンIII が 8 世帯、パタンIVが 3 世帯であった（表 4)。つまり、再定住地に おいて約 $72 \%$ の世帯（パタン I，II）が MC の関係を継承し、特に $8 \%$ の世帯 (パタンII ) が血縁によらずに MC の関係を継承している。

\section{（2）組み合わせパタンI（MC の関係のみ有する）}

「住宅移転前の従前居住地」において組み合わせパタン II を有して いた再定住地 $\mathrm{G}$ 居住者 20 世帯が、「住宅移転後の従前居住地」にお いて有するパタンの内訳は、パタン I が 0 世帯、パタン II が 6 世帯、 パタンIIIが 0 世帯、パタンIVが 14 世帯であった（表 3)。つまり、従 前居住地において $30 \%$ の世帯（パタン II ）が地縁・血縁によらずに $\mathrm{MC}$ の関係を維持している。

また、パタン II を有していた 20 世帯が、再定住地において有する パタンの内訳はパタン I が 0 世帯、パタン II が 14 世帯、パタンIII が 0 世帯、パタンIVが 6 世帯であった（表 4)。つまり、再定住地にお いて 70\%の世帯（パタンII）が血縁関係によらずに MC の関係を継 承している。

\section{（3）組み合わせパタン正（血縁関係のみ有する）}

「住宅移転前の従前居住地」において組み合わせパタンIII を有して いた再定住地 $\mathrm{G}$ 居住者 17 世帯が、「住宅移転後の従前居住地」にお いて有するパタンの内訳は、パタン I が 0 世帯、パタン II が 0 世帯、 パタンIIIが 6 世帯、パタンIVが 11 世帯であった（表 3)。つまり、従 前居住地において MC の関係を新たに形成した世帯はいない。

また、パタンIII を有していた 17 世帯が、再定住地で有するパタン の内訳は、パタン I が 3 世帯、パタン II が 0 世帯、パタンIIIが 7 世 帯、パタンIVが 7 世帯であった（表 4)。つまり、再定住地において 約 $18 \%$ の世帯（パタン I， II）が MC の関係を新たに形成している。

\section{（4）組み合わせパタンIV（MC の関係と血縁関係ともになし）}

「住宅移転前の従前居住地」において組み合わせパタンIVを有して
表 4 従前居住地から再定住地への 組み合わせパタンの変化

\begin{tabular}{|c|c|c|c|c|c|}
\hline \multirow{2}{*}{\multicolumn{2}{|c|}{$\begin{array}{l}\text { (3) } \\
\text { (1) } \\
\text { (1) } \\
\text { 移転前の } \\
\text { 従地前住地 }\end{array}$}} & I & II & III & IV \\
\hline & & $\begin{array}{l:l}0 & 1 \\
0 & 0 \\
& 0\end{array}$ & $\begin{array}{lll}1 & 0 \\
1 & 0\end{array}$ & $8 \begin{array}{l}1 \\
1 \\
1\end{array}$ & $\begin{array}{l}1 \\
1 \\
1 \\
1\end{array}$ \\
\hline \multirow[t]{2}{*}{ I } & \multirow[t]{2}{*}{ 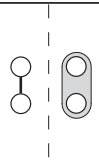 } & $\begin{array}{ccccc}1 & 3 & 6 & 7 & 12 \\
14 & 16 & 17 & 18 & 19 \\
25 & 27 & 28 & 33 & 36 \\
41 & 87 & 96 & 100 & \end{array}$ & 30 & 3886 & 22 \\
\hline & & 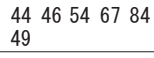 & 5942 & $\begin{array}{l}5053566263 \\
69\end{array}$ & 4573 \\
\hline \multirow{2}{*}{ II } & \multirow{2}{*}{$\begin{array}{ll}1 & \\
1 & 0 \\
1 & 0 \\
1 & \end{array}$} & & $\begin{array}{ccccc}2 & 5 & 10 & 24 & 29 \\
35 & 40 & 98 & 99\end{array}$ & & 81120 \\
\hline & & & 6166767991 & & 827794 \\
\hline \multirow{2}{*}{ III } & \multirow{2}{*}{$\begin{array}{ll} & 1 \\
0 & 1 \\
0 & 1 \\
1 & 1 \\
1\end{array}$} & 931 & & 4 & 8932 \\
\hline & & 58 & & $\begin{array}{l}4347516885 \\
72\end{array}$ & 6078938890 \\
\hline \multirow{2}{*}{ IV } & \multirow{2}{*}{$\begin{array}{l}1 \\
1 \\
1 \\
1\end{array}$} & & 26 & & 13399721 \\
\hline & & & 1016580 & & 5275 \\
\hline
\end{tabular}

(上段の数字) «ペラナ村から転入した世帯の世帯番号 (図4, 図 5 と対応)

(下段の数字) Ł ミリッサ村、その他の村から転入した世帯の世帯番号 (図 4, 図 5 と対応)

いた再定住地 $\mathrm{G}$ 居住者 10 世帯が、「住宅移転後の従前居住地」にお いて有するパタンの内訳はパタン I が 0 世帯、パタン II が 0 世帯、 パタンIIIが 0 世帯、パタンIVが 10 世帯であった（表 3)。つまり、従 前居住地において MC の関係を新たに形成した世帯はいない。

また、パタンIVを有していた 10 世帯が、再定住地で有するパタン の内訳は、パタン I が 0 世帯、パタン II が 4 世帯、パタン III が 0 世帯、 パタンIVが 6 世帯であった（表 4)。つまり、再定住地において 40\% の世帯 (パタン I ， II ) が血縁によらずに MC の関係を形成している。

\section{4.MCの関係の維持・継承と従前居住地の関連性}

\section{(1) 従前居住地の経済的安定性との関連性}

$\mathrm{MC}$ の関係の維持・継承を従前村別にみると、従前居住地の $\mathrm{MC}$ に 参加していた世帯は、ペラナ村から転入した世帯（以下、「ペラナ村 世帯」とする）が全 45 世帯のうち 35 世帯であり、ミリッサ村とそ の他の村から転入した世帯（以下、「ミリッサ村世帯」とする）が全 41 世帯のうち 24 世帯であった。従前居住地において住宅移転後も $\mathrm{MC}$ への参加を継続している世帯は、ペラナ村世帯が 15 世帯、ミリ ッサ村世帯が 15 世帯であった。再定住地において MC に参加する世 帯は、ペラナ村世帯が 32 世帯、ミリッサ村世帯が 17 世帯であった。

このように、ペラナ村世帯とミリッサ村世帯ともに多くの世帯が $\mathrm{MC}$ に参加しているが、ペラナ村世帯のほうがミリッサ村世帯よりも 参加寸る世帯の割合が高い。先述したようにペラナ村世帯はミリッ サ村世帯に比べて経済的に不安定であり、上記の分析結果は、経済 的に不安定な居住者ほど MC をより必要としており、居住者にとっ て MC の関係が経済的関係として重要であることを裏付けている。

\section{(2) 従前居住地の地縁関係との関連性}

再定住地の MC に参加する世帯の内訳を従前ワッタ別にみると、 ペラナ村・ワッタ A が 19 世帯のうち 13 世帯が参加（13 世帯 / 19 世 帯)、同・ワッタ B が 5 世帯 $/ 6$ 世帯、同・ワッタ C が 4 世帯 $/ 5$ 世帯、 同・ワッタ D が 4 世帯 $/ 6$ 世帯、同・ワッタ E が 3 世帯 / 4 世帯、同・ 
ワッタ $\mathrm{F}$ が 2 世帯 $/ 3$ 世帯、同・ワッタ $\mathrm{G}$ が 1 世帯 $/ 2$ 世帯、ミリッ サ村・ワッタ $\mathrm{H}$ が 2 世帯 $/ 6$ 世帯、同・ワッタ I が 12 世帯 $/ 28$ 世帯、 同・ワッタ J が 1 世帯 $/ 3$ 世帯、同・ワッタ $\mathrm{K}$ が 1 世帯 $/ 1$ 世帯、他・ ワッタ L が 0 世帯 $/ 2$ 世帯、他・ワッタ $\mathrm{M}$ が 1 世帯 $/ 1$ 世帯であった。 再定住地の MC に参加する 49 世帯のうち、32 世帯は従前ワッタが 同じ世帯と同じ MC グループに参加しており、多くの世帯が従前居 住地の地縁関係者とともに MC グループに参加している（図 5）。

また、従前ワッタが同じ世帯と同じ MC グループに参加する 32 世 帯は19 世帯が再定住地に血縁関係を有し、同じ MC グループには参 加しない 17 世帯も 8 世帯が再定住地に血縁関係を有する。

先述したように再定住地 $\mathrm{G}$ では従前の村およびワッタのまとまり で住宅配置が決められており、MCグループを結成する際に従前居住 地の地縁関係および血縁関係が活用されたと考えられる。

\section{5. M Cの関係の維持 - 継承と住宅敷地所有・利用関係の関連性}

\section{(1) 住宅移転前後の住宅敷地所有・利用関係の変化}

再定住地 $\mathrm{G}$ 居住者 86 世帯の従前居住地における住宅敷地所有・利 用関係の内訳は、「共有敷地の共同利用」が 6 世帯、「私有敷地の共 同利用」が 29 世帯、「私有敷地の私的利用」が 51 世帯であった。「共 有敷地の共同利用」世帯のうち 5 世帯が従前居住地に血縁関係を有し、 「私有敷地の共同利用」世帯のうち 26 世帯が従前居住地に血縁関係 を有していた。従前居住地では、主に血縁関係者間で住宅敷地の共 同所有や共同利用が行われていたと考えられる。

従前居住地において住宅敷地利用を継続している世帯は26世帯で あり、そのうち「共有敷地の共同利用」が 1 世帯、私有敷地の共同利用」 が 10 世帯、「私有敷地の私的利用」が 15 世帯であった。従前居住地 の住宅敷地は、仕事場に近く生計手段となる資源が周辺に豊富であ るため、住宅移転後も作業場や作物の栽培などに利用されている。

再定住地における住宅敷地所有・利用関係の内訳は、「共有敷地の 共同利用」が 0 世帯、「私有敷地の共同利用」が 4 世帯、「私有敷地 私的利用」が 82 世帯であった。再定住地では住宅の私的所有権が居 住者に与えられ、住宅敷地の共同利用がほとんど行われていない。

\section{（2）MCの関係の維持・継続と住宅敷地所有・利用の関連性}

住宅移転後も従前居住地の $\mathrm{MC}$ へ参加を継続している再定住地 居住者 30 世帯のうち、10 世帯が従前居住地の住宅敷地利用を継続し ている。 MC グループには住宅敷地周辺の生計手段の活用に取り組ん でいるグループも多く、従前居住地における住宅敷地利用の継続が $\mathrm{MC}$ の関係の維持を促している可能性がある。

一方、 $\mathrm{MC}$ への参加を継続している 30 世帯のうち 20 世帯は従前居 住地の住宅敷地利用を継続しておらず、さらにそのうち 18 世帯は従 前居住地に血縁関係世帯が居住していないが MCへの参加を継続し ている。このことは、MCの関係が地縁関係、血縁関係、住宅敷地利 用関係によらずに維持される場合があることを示している。

\section{4. 結論}

本稿では、被災者の生活再建が比較的良好に進んでいると推測さ れる再定住地 $\mathrm{G}$ において、従前の地域コミュニティにおける居住 者間の関係がどのように再編されているかを、マイクロクレジット (MC) の関係の維持・継承に着目して明らかにした。

まず、再定住地 $\mathrm{G}$ 居住者 86 世帯のうち、59 世帯が従前居住地に おいて MC に参加していたこと、30 世帯が住宅移転後も従前居住地
の MCへの参加を継続し MCの関係を維持していることが明らかに なった。また、再定住地において 49 世帯が MC に参加し、MC の関 係を継承していることが明らかになった。

$\mathrm{MC}$ の関係が維持・継承されていることは、MCの関係が経済的関 係として居住者に重視されていることの表れである。このことは経 済的に不安定なぺラナ村世帯が経済的に比較的安定なミリッサ村世 帯よりも MC に参加する世帯の割合が高いことからも確認できた。

さらに、世帯間関係の組み合わせパタンと住宅敷地所有・利用関 係の分析を行うことで MC の関係の維持・継承と地縁関係、血縁関係、 敷地所有利用関係の関連性を明らかにし、調查対象地域における MC の関係の性質について考察した。分析結果を以下に示す。

1) 従前居住地の $\mathrm{MC}$ に参加する再定住地 $\mathrm{G}$ 居住者 30 世帯のう ち 24 世帯が従前居住地に血縁関係世帯が居住していなくとも MC の 関係を維持していること、20 世帯が従前居住地の住宅敷地利用を継 続していなくとも MC の関係を維持していることが明らかになった。 これらの世帯は居住地の範囲を超えて MC の関係を維持しているこ とから、MCの関係は地縁関係によらずに維持され得ると考えられ、 さらに上記の結果から MC の関係は、地縁関係、血縁関係、住宅敷 地利用関係によらずに維持され得るとも考えられる。

2）再定住地 $\mathrm{G}$ の $\mathrm{MC}$ に参加する 49 世帯のうち、17 世帯は従前居 住地からの地縁関係者と同じ MC グループに参加していないこと、 21 世帯が再定住地に血縁関係者が居住していなくとも MC に参加し ていることが明らかになった。一方で、32 世帯が従前居住地からの 地縁関係者と同じ MC グループに参加し、そのうち 19 世帯が再定住 地 $\mathrm{G}$ に血縁関係者が居住することが明らかになった。上記の結果は、 再定住地において MC の関係が形成される際、再定住地に継承され た従前居住地の地縁関係や血縁関係が活用されたことを示唆する。

以上のように、再定住地 $\mathrm{G} へ$ 移住において $\mathrm{MC}$ の関係は、地縁・ 血縁といった非選択的関係にある者との間だけでなく、地縁・血縁 関係者以外の者との間でも維持・継承されている。このことから、 $\mathrm{MC}$ の関係は選択的関係としての性質を備えていたと考えられる。

自然災害後の住宅復興は被災者の生活再建のし易さを考慮すると 被災地での住宅再建が基本的には望ましい。しかし、被災地での住 宅再建が可能でない場合や望ましくない場合も存在する。そこで本 研究は、被災地外への住宅移転が避けられないケースを想定して、 被災者の生活再建をサポートする居住者間の関係に着目し、住宅移 転における地域コミュニティの維持・継承のあり方を検討してきた。

前稿 3) では住宅移転において従前の居住者間の関係を全て再定住 地に継承する「再定住地完結型」再定住は必ずしも現実的ではない ことを指摘した。そして本稿では、再定住地 $\mathrm{G}$ において居住者間の 関係を部分的に維持・継承する「従前居住地一再定住地補完型」に 近い再定住が MC の関係を介して実現していることを明らかにした。

これは、住宅移転において「従前居住地一再定住地補完型」再定 住を想定する必要があることを支持する知見である。また、そのよ うな再定住を実現するために、地縁・血縁といった非選択的関係だ けでなく、MCの関係のような選択的関係の維持・継承にも配慮する 必要があることを支持する知見である。以上が本稿の結論である。

なお、再定住地 $\mathrm{G}$ に移住した被災者の生活再建がどのように行わ れているか、生活再建において MCによ゙のような効果があったかは 本稿では具体的には検討していない。これについては別稿としたい。 
謝辞

実地調査では、Green Movement of Sri Lanka コロンボ本部および同 マータラ支部の職員の方々、NPO 法人アプカス・スリランカ事務所 の石川直人氏にご協力頂いた。ここに記して謝意を表したい。

注

注 1) 本研究では、「再定住」を「自然災害、戦争・紛争、開発事業など何ら かの要因によって住宅移転ないし住宅敷地利用の変化を迫られた居住者が、 安定的居住に必要とする社会関係および居住空間を維持・回復し生活再建一 と向からプロセス」という意味で用いている（文献 3 を参照）。

注 2) 2004 年 12 月 26 日に発生したインド洋スマトラ沖地震津波によって、 スリランカ（人口約 1960 万人）では死者・行方不明者約 3.6 万人の人的被 害と全半壊住宅約 7.8 戸の全半壊住宅被害が生じ、少なくとも 87 万人が住 居を失ったと言われる (文献 14 参照)。住宅復興政策において必要戸数約 10.6 万戸のうち約 3.6 万戸が住宅移転の対象となり、全 351 ヶ所の再定住 地が建設された (文献 4 参照)。筆者らによる住宅德興および居住者の再定 住プロセスに関する調查については文献 3 、文献 4 、文献 5 を参照。

注 3) 2008 年 12 月にウェリガマ郡の再定住地全 14 ケ所を訪れ、空き家の発 生状況、共用施設の運営、組織の活動などを調查した。再定住地の中には、 多くの空き家が発生し定住率が既に $50 \%$ 以下となっている再定住地がみら れた（再定住地 A、本文中の図 1 、図 2 を参照)。

注 4) マイクロクレジットとは、主に低所得層を対象とした非常に小額の融 資や貯蓄などの金融サービスである。 $5 \sim 15$ 人程度のグループに対して金 融サービスや生活向上のためのサービスが提供される（文献 16 を参照）。

注 5) 文献 1 および文献 2 などにおいて指摘されている。

注 6) 文献 6、文献 7 などにおいて指摘されている。

注 7) 文献 6, pp.123-125 を参照。

注 8) 文献 $6, p .124$ および文献 9 を参照。

注 9) 阪神・淡路大震災において、被災地に居住していた人々の $25.3 \%$ が被 害程度と関係なく震災後に居住地を移動したことが明らかにされている（文 献 8, p.23)。また、新潟県中越地震においても、仮設住宅地への入居は基本 的に既存の集落単位で行われたが、その後の恒久住宅の建設では個別の自力 建設や、集落の分散が発生し、既存の集落コミュニティが大きく変容したと 言われている (文献 $6, p .125$ 参照)。

注 10) 文献 10、pp.29-38 を参照。中根による「家族構造の 3 つのモデル」 は下記の図で表される (文献 10, p.36)。図中の点線は、結婚後、独立した 世帯や住居を構える夫婦を表す。中根は、スリランカとイギリスを例に小家 族構成が社会の基準として強く打ち出され実行されてきた社会について考察 し、インドを例に家族集団の拡大が志向され大家族が形成されてきた社会に ついて、日本の村落を例に家族集団の存続が志向され父一息子の継承線を特 色とする家族が形成されてきた社会について考察している（文献 10）。
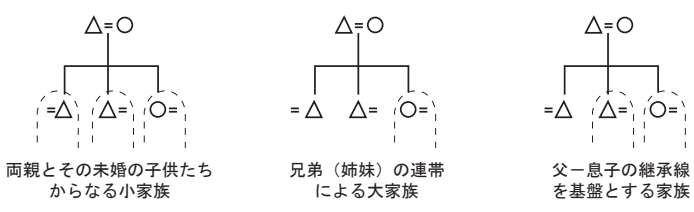

注 11) シンハラ人社会には、「ゲー」と呼ばれる「食事を共にする単位」がある。 ゲーは「妻、未婚の子供、夫で構成され、常に別個の台所と倉庫を持つ」独 立性の高い単位であり（文献 12, p.102）、通常、経済活動の単位とも一致し ている。1 棟の家屋に複数のゲーがある場合もあるが、1 棟の家屋に一つの ゲーである場合が一般的であることが既往研究において確認されている（文 献 12 , p.115 および文献 11, p.298 を参照)。

注 12）文化人類学者の高桑史子は、スリランカ南部の海村の調査をもとに、 核家族に加えて結婚した子供が同居している場合も多いが、これはあくまで 過渡的な居住形態であり、結婚したての子供は適当な家がないので親の家に 同居しているだけであって、理想的には核家族を志向していると述べている (文献 11, pp.293-299 を参照)。

注 13) インド洋津波被災直後の緊急時においても、血縁・親族関係を通じて 住居の提供が行われるなど、居住者間の関係が機能した（文献 4)

注 14) ウェリガマ郡では人口約 6.6 万人、住宅数 9332 戸のうち、2004 年 12 月のインド洋津波によって死者数 345 人、全半壊住宅数 2810 戸の被害が生 じた。同郡の人口・住宅は文献 13 を、津波被害は文献 14 を参照。

注 15) 再定住地における住宅供給戸数は、2008 年 5 月にウェリガマ郡役所
で行った聞き取り調査にもとづく。ウェリガマ郡では、一つの村から平均約 2.8 ケ所の再定住地に分散して居住者が移住しており、まとまりの規模は平 均約 8.6 世帯であった（文献 4, p. 98 を参照）。

注 16) 津波被害の統計によると、ペラナ村では住宅 377 戸のうち 244 戸が全 壞し、ミリッサ村では 473 戸のうち 22 戸が全壊した。文献 14 を参照。

注 17) 文献 15 によると、2003 年現在、スリランカの漁業従事世帯 12 万 6819 世帯の 9 割以上が船外機付小型漁船や無動力の伝統漁船、小型動力船 を使用して沿岸魚を獲る小規模漁民である。聞き取り調査によると、ペラナ 村居住者は主に、動力無しの小型漁船で浜辺から漁に出るタイプであり、漁 獲が天候や季節の影響を受けや寸く不安定である。一方、ミリッサ村の居住 者は主に、動力付きの中型・大型漁船で漁港から漁に出るタイプであり、漁 獲が天候や季節の影響を受けにくく比較的安定している。

注 18) 再定住地の定住率に影響する要因としてまず、居住者の主な生業であ る漁業の継続が考えられる。ウェリガマ郡では、海から離れて立地する再定 住地ほど定住率が低下する傾向がみられた。しかし、再定住地・事例 A の ように、海からそれほじ離れていない再定住地であっても、定住率の低い再 定住地がみられた。再定住地・事例 A では、従前居住地コミュニティの規 模や地縁に無配慮な計画が行われていることから、生業の継続に加え、コミ ユニティの維持も再定住地の定住率に影響する要因であると考えられる。

注 19) 血縁・親族関係を介して行われる世帯間の相互扶助は、親と子供、兄 弟姉妹の関係など概ね 2 親等以内の親族以内で行われる傾向があることが既 往研究で指摘されている (文献 11 を参照)。

注 20) ウェリガマ郡ではインド洋津波以前から行政や NGO による MC の活 動が盛んであり、再定住地 $\mathrm{G}$ 居住者は再定住地で活動する $\mathrm{MC}$ グループだ けでなく従前居住地で活動する MC グループにも参加している。

\section{参考文献}

1) 高田光雄 : 住宅復興における取り組み, 復興 10 年総括検証・提言事業, 兵庫県, 2005

2) 竹原祐介, 高田光雄, 住田昌二, 澤谷真紀子, 山崎古都子 : 阪神・淡路大 震災による被災者の住宅・住生活再建プロセスに関する研究, 都市住宅学 16 号, pp.134-142, 1996

3) 前田昌弘, 高田光雄, 神吉紀世子 : 世帯間関係と住宅敷地所有・利用関係 による再定住の類型化一インド洋津波後のスリランカにおける住宅移転をと もなう再定住に関寸る研究 その $1-$, 日本建築学会計画系論文集, 第 75 巻, 第 652 号, pp.1441-1448, 2010.6

4）前田昌弘：スリランカにおける居住地移転をともなう住宅再建事業の現状 と課題, 林勲男 (編) : 自然災害と復興支援（みんぱく実践人類学シリーズ 第 9 巻), pp.87-108, 明石書店, 2010

5) 前田昌弘, 高田光雄, 神吉紀世子 : スリランカ漁業世帯の菜園付戸建再定 住地における居住状況一居住地移転前後の世帯間関係の変化と継続性に着目 して一，住宅系研究報告会論文集 4, pp.177-186, 2009. 12

6）浦野正樹, 吉井忠寛, 大矢根 淳 (編): 復興コミュニティ論入門（シリ ーズ災害と社会 第 2 巻), 弘文堂, 2007

7）兵庫県まちづくり部：住まい復興の記録一ひょうご住宅復興 3 ケ年計画の 足跡, 2000

8）林春男：阪神・淡路大震災からの生活復興 2001- パネル調査結果報告書, 京都大学防災研究所巨大災害研究センター・テクニカルレポート, 2001

9）新潟県中越大震㷋記録誌編集委員会 (編)：中越大震災 前編一雪が降る前 に,ぎょうせい, 2006

10）中根千枝 : 家族の構造一社会人類学的分析, 東京大学出版会, 1970

11）高桑史子：スリランカ海村の民族誌 - 開発 - 内戦・津波と人々の生活, 明石書店, 2008

12) N.Yalman : Under the Bo Tree -Studies in Caste,Kinship \& Marriage in the Interior of Ceylon,University of California Press,1967

13) Department of Census and Statistics:Census of Population and Housing 2001,2001

14) Department of Census and Statistics:Final Report - Census on the buildings and people affected by the Tsunami disaster 2004,2005

15) B.Wijayaratne:Coastal Fisheries in Sri Lanka-Some Recommendations for Future Management UNU-Fisheries Training Programme Final Project 2001,The United Nation University,2003

16) 岡本真理子, 吉田秀美, 粟野晴子 : マイクロファイナンス読本, 明石書 店, 1999 